Dear Author,

Please, note that changes made to the HTML content will be added to the article before publication, but are not reflected in this PDF.

Note also that this file should not be used for submitting corrections. 


\title{
Selecting cost effective and policy-relevant biological indicators for European monitoring of soil biodiversity and ecosystem function
}

\author{
, Q1 B.S. Griffiths ${ }^{\mathrm{a}, *}$, J. Römbke $^{\mathrm{b}}$, R.M. Schmelz ${ }^{\mathrm{b}}$, A. Scheffczyk ${ }^{\mathrm{b}}$, J.H. Faber ${ }^{\mathrm{c}}$, J. Bloem ${ }^{\mathrm{c}}$, \\ G. Pérès ${ }^{d}$, D. Cluzeau ${ }^{\mathrm{e}}$, A. Chabbi ${ }^{\mathrm{f}}$, M. Suhadolc ${ }^{\mathrm{g}}$, J.P. Sousa ${ }^{\mathrm{h}}$, P. Martins da Silva $^{\mathrm{h}}$, \\ F. Carvalho ${ }^{h}$, S. Mendes ${ }^{h}$, P. Morais ${ }^{h}$, R. Francisco $^{h}$, C. Pereira ${ }^{h}$, M. Bonkowski ${ }^{i}$, S. Geisen ${ }^{i}$, \\ R.D. Bardgett ${ }^{\mathrm{j}}$, F.T. de Vries $^{\mathrm{j}}$, T. Bolger ${ }^{\mathrm{k}}$, T. Dirilgen ${ }^{\mathrm{k}}$, O. Schmidt ${ }^{\mathrm{l}}$, A. Winding ${ }^{\mathrm{m}}$, \\ N.B. Hendriksen ${ }^{\mathrm{m}}$, A. Johansen ${ }^{\mathrm{m}}$, L. Philippot ${ }^{\mathrm{n}}$, P. Plassart ${ }^{\mathrm{n}}, \mathrm{D}$. Bru ${ }^{\mathrm{n}}$, B. Thomson ${ }^{\mathrm{O}}$, \\ R.I. Griffiths ${ }^{\circ}$, M.J. Bailey ${ }^{\circ}$, A. Keith ${ }^{\mathrm{p}}$, M. Rutgers ${ }^{\mathrm{q}}$, C. Mulder ${ }^{\mathrm{q}}$, S.E. Hannula ${ }^{\mathrm{r}}$, R. Creamer $^{\mathrm{s}}$, \\ D. Stone ${ }^{\mathrm{s}}$ \\ ${ }^{a}$ Crop and Soil Systems Research Group, SRUC, Edinburgh EH9 3JG, UK \\ ${ }^{\mathrm{b}}$ ECT Oekotoxikologie GmbH, Flörsheim, Germany \\ c Alterra, Wageningen UR, PO Box 47, 6700AA, The Netherlands \\ ${ }^{\mathrm{d}}$ Agrocampus Ouest INRA Rennes, France \\ e University of Rennes, CNRS OSUR-EcoBio, France \\ ${ }^{\mathrm{f}}$ INRA Poitou Charentes, UR P3F ans Ecosys Grignon, France \\ ${ }^{\mathrm{g}}$ University of Ljubljana, Biotechnical Faculty, Ljubljana, Slovenia \\ ${ }^{\mathrm{h}}$ Department of Life Sciences, University of Coimbra, Portugal \\ i Department of Terrestrial Ecology, Institute of Zoology, University of Cologne, Zülpicher Str 47b, D-50674 Cologne, Germany \\ ${ }^{\mathrm{j}}$ Faculty of Life Sciences, Michael Smith Building, The University of Manchester, Manchester M13 9PT, UK \\ ${ }^{\mathrm{k}}$ School of Biology and Environmental Science, University College Dublin, Belfield, Dublin 4, Ireland \\ ${ }^{1}$ School of Agriculture and Food Science, University College Dublin, Belfield, Dublin 4, Ireland \\ $\mathrm{m}$ University of Aarhus, Department of Environmental Science, Roskilde, Denmark \\ ${ }^{\mathrm{n}}$ INRA Dijon, France \\ ${ }^{\circ}$ Centre for Ecology \& Hydrology, MacLean Building, Benson Lane, Crowmarsh Gifford, Wallingford, Oxfordshire OX10 8BB, UK \\ ${ }^{\mathrm{P}}$ Centre for Ecology \& Hydrology, Lancaster Environment Centre, Library Avenue, Bailrigg, Lancaster LA1 4AP, UK \\ ${ }^{\mathrm{q}}$ National Institute for Public Health and the Environment (RIVM), Bilthoven, The Netherlands \\ ${ }^{\mathrm{r}}$ NIOO-KNAW, Netherlands \\ s Teagasc, Johnstown Castle Research Centre, Ireland
}

\section{A R T I C L E I N F O}

Article history:

Received 13 July 2015

Received in revised form 7 April 2016

Accepted 11 April 2016

Available online xxx

\section{Keywords:}

Climatic zone

Ecosystem services

Land use

Logical sieve

Soil fauna

Soil microbiology

\begin{abstract}
A B S T R A C T
Soils provide many ecosystem services that are ultimately dependent on the local diversity and belowground abundance of organisms. Soil biodiversity is affected negatively by many threats and there is a perceived policy requirement for the effective biological monitoring of soils at the European level. The aim of this study was to evaluate and recommend policy relevant, cost-effective soil biological indicators for biodiversity and ecosystem function across Europe. A total of 18 potential indicators were selected using a logical-sieve based approach. This paper considers the use of indicators from the 'top down' (i.e. concerned with the process of indicator selection), rather than from the 'bottom up' detail of how individual indicators perform at specific sites and with specific treatments. The indicators assessed a range of microbial, faunal and functional attributes newer nucleic acids based techniques, morphological approaches and process based measurements. They were tested at 6 European experimental sites already in operation and chosen according to land-use, climatic zone and differences in land management intensity. These were 4 arable sites, one each in Atlantic, Continental, Mediterranean and Pannonian climate zones, and 2 grassland sites, one each in Atlantic and Continental zones. At each site we sampled three replicated plots of contrasting management intensity and, while the treatments varied from site to site, their disturbance effects were quantified in terms of land use intensity. The field sampling and laboratory analysis were standardised through a combination of ISO protocols, or standard operating procedures if the former were not available. Sites were sampled twice, in autumn 2012 and spring or autumn 2013,
\end{abstract}


with relative costs of the different indicators being determined each time. A breakdown of the cost effectiveness of the indicators showed the expected trade-off between effort required in the field and effort required in the laboratory. All the indicators were able to differentiate between the sites but, as no single indicator was sensitive to all the differences in land use intensity, we suggest that an indicator programme should be based upon a suite of different indicators. For monitoring under the European climatic zones and land uses of this study, indicators for ecosystem functions related to the services of water regulation, C-sequestration and nutrient provision would include a minimum suite of: earthworms; functional genes; and bait lamina. For effective monitoring of biodiversity all taxonomic groups would need to be addressed.

@ 2016 Published by Elsevier Ltd.

\section{Introduction}

Human societies are highly dependent upon healthy soils for the delivery of ecosystem goods and services, including provisioning (food, fibre, timber, fuel), regulation (climate, disease, natural hazards), waste treatment, nutrient cycling and cultural services (Millennium Ecosystem Assessment, 2005). Many of the key functions supporting these ecosystem services depend to a large extent upon the diversity, abundance and activity of organisms that inhabit the soil. This diversity varies in terms of its taxonomic richness, relative abundance and distribution according to soil type, climatic conditions, vegetation and land use. Against this background, soil biodiversity is also subject to various threats associated with human activity, including soil erosion, organic matter decline, and contamination, salinisation, sealing, compaction of soil and climate change; all these threats impair soil biodiversity and functioning with negative consequences on ecosystem service delivery (Hooper et al., 2005; Gardi et al., 2013; Wall et al., 2012). Increasing agricultural intensity, for example, has been shown to generally reduce soil biodiversity (e.g. Tsiafouli et al., 2015), although this response is likely to be non-linear given the variation in management practices and soil conditions across sites and regions, and differences in the sensitivity of soil organism groups to management intensity. As a result, there is a strong and increasing policy requirement for the effective monitoring of soils at local, regional and national scales (EU, 2006a,b; Ritz et al., 2009; Turbé et al., 2010; Cluzeau et al., 2012). Moreover, this need has been stimulated by the Convention on Biological Diversity (http://www.cbd.int/), which includes a requirement for indicators capable of monitoring changes in soil biodiversity (Pulleman et al., 2012).

Most soil processes are mediated by soil biota in direct relationship with the physico-chemical properties of their environment. Furthermore, soil organisms have the ability to adapt rapidly to changes in climate and soil management in an integrative way, which makes them good indicators (e.g. as argued for by Ritz and Trudgill, 1999). Biodiversity is a soil attribute in itself and therefore relevant to an ecosystem level approach (Doran and Zeiss, 2000; Loreau, 2000; Lemanceau et al., 2015). Biological indicators, therefore, are relevant for use in supporting policy and decision making to achieve sustainable soil management (Francaviglia, 2008; Pulleman et al., 2012; Havileck, 2012). The application of biological indicators to assess changes in the delivery of ecosystem functions is accepted practice both at national and European scales (Feld et al., 2009; Pulleman et al., 2012; Faber et al., 2013; Lemanceau et al., 2015). Some applications derive from an ecotoxicological perspective (e.g. Van Straalen, 1998; Becaert and Deschenes, 2006). However, no reference set of standardised biological indicators is available yet (Pulleman et al., 2012), largely because of the variation in scope, goal and duration of monitoring schemes (Turbé et al., 2010). Biological indicators have long been developed and applied in specific environmental situations, making the extrapolation of values and applicability under different conditions difficult. Furthermore, despite recent efforts to standardise, a wide range of different methods and procedures are applied, preventing meaningful comparison of conclusions. National (Gardi et al., 2009; Rutgers et al., 2009) and European (e.g. ENVASSO, Bispo et al., 2009) initiatives have been undertaken to recommend indicators across Europe and elsewhere (Ditzler and Tugel, 2002; Black et al., 2003; Turbé et al., 2010; Pulleman et al., 2012).

Reviews have compared a large range of biological indicators for scientific and technical relevance to assist policy-makers in land management (Ritz et al., 2009; Pulleman et al., 2012; Turbé et al., 2010; Aalders et al., 2009; Bispo et al., 2009; Paz-Ferreiro and Fu, 2016), with the consensus being that major efforts remain to be made in order to standardise operational procedures and to valiselection of potential biological indicators is only a step in developing a practical monitoring scheme (Doran and Zeiss, 2000), as there are operational issues to be solved such as: ease of application, robustness, sensitivity, laboratory accuracy, throughput, economic value and descriptiveness. The selection criteria for biological indicators are well described (e.g. Turbé et al., 2010; Ritz et al., 2009; Aalders et al., 2009) but consideration also has to be given to the cost-effectiveness of the indicators and the interpretation of the results from the monitoring. Different stakeholders have different information needs, and different indicators have to be developed to answer their specific requirements (Turbé et al., 2010).

The aim of this study was to evaluate and recommend policy relevant and cost-effective soil biological indicators for biodiversity and ecosystem function across Europe. Indicators were selected and validated by a detailed examination at European experimental sites chosen according to land-use, climatic zone and differences in land management intensity. We sought to develop indicators applicable across Europe with no particular management treatment in mind, using a range of treatments/land-use/climatic zones to assess the generality of the indicator performance and information on their practicalities and costs to determine cost-effectiveness. As we are concerned with the process of indicator selection we consider the use of indicators from a 'top down' approach, rather than the 'bottom-up' detail of how individual indicators perform at specific sites and with specific treatments. The objectives of this study were to describe: the selection process for potential indicators to field test; criteria for the selection of sites at which to evaluate the indicators; standardisation of the field sampling; interpretation of the data; and recommendations for the use of biological indicators for soil biodiversity and ecosystem function at the European scale.

\section{Materials and methods}

\subsection{Selection of indicators}

There are approaching 200 biological methods that could potentially be used in a soil monitoring programme (Ritz et al., 2009; Aalders et al., 2009). To reduce this to a manageable number for testing an initial list of 30 potential indicators (Table 1), date them for different types of land use (Faber et al., 2013). The 
Table 1

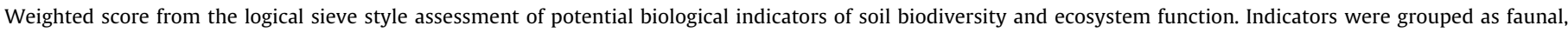

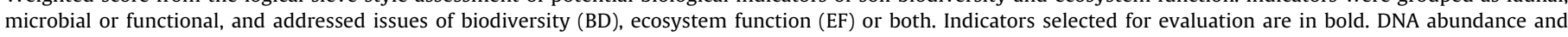

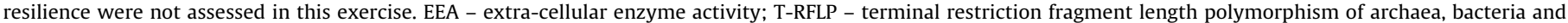
fungi; PLFA - phospho-lipid fatty acid analysis. Indicators evaluated in the field but not ranked in this assessment are included for completeness and scored n/a.

\begin{tabular}{|c|c|c|c|}
\hline Potential indicator & Indicator group & Issue addressed & Weighted score \\
\hline Nematodes: molecular & Fauna & BD/EF & 659 \\
\hline Nematodes: morphological & Fauna & & 640 \\
\hline Enchytraeids: molecular & Fauna & & 639 \\
\hline Mites: molecular & Fauna & & 639 \\
\hline Collembola: molecular & Fauna & & 639 \\
\hline Earthworms: morphological & Fauna & BD/EF & 633 \\
\hline Collembola: morphological & Fauna & BD/EF & 623 \\
\hline Enchytraeids: morphological & Fauna & BD/EF & 623 \\
\hline Mites: morphological & Fauna & BD/EF & 611 \\
\hline Earthworms - molecular & Fauna & $p$ & 599 \\
\hline Fungi (ergosterol) & Microbe & BD & 549 \\
\hline Protista - molecular & Microbe & & 539 \\
\hline Nitrification & Function & $\mathbf{E F}$ & 525 \\
\hline Potentially mineralisable $\mathrm{N}$ & Function & EF & 525 \\
\hline Hot water extractable C & Function & EF & 525 \\
\hline Respiration & Function & $\mathrm{EF}$ & 507 \\
\hline Bait Lamina & Function & EF & 492 \\
\hline EEA & Function & EF & 474 \\
\hline Microbial - T-RFLP & Microbe & BD & 473 \\
\hline PLFA & Microbe & BD & 459 \\
\hline Functional genes & Function & BD/EF & 448 \\
\hline Protista - morphology & Microbe & & 446 \\
\hline Denitrification & Function & & 422 \\
\hline Pyrosequencing & Microbe & & 415 \\
\hline MicroResp & Function & EF & 398 \\
\hline Water infiltration & Function & $\mathbf{E F}$ & 398 \\
\hline Molecular Chip technology & Microbe & & 383 \\
\hline Other 'omic' methods & Microbe & & 328 \\
\hline DNA abundance & Microbe & EF & n/a \\
\hline Resilience & Microbe & $\mathbf{E F}$ & $\mathbf{n} / \mathbf{a}$ \\
\hline
\end{tabular}

including developing as well as established methods in soil ecology, was prepared by a panel of approximately 50 European soil biology researchers. There was an even spread of experts with experience in at least one of the following fields: soil functional determinations; soil fauna; microbial ecology; and the use of state-of-the-art molecular analyses. This 30 was then reduced to a logistically feasible number for evaluation using a logical sieve assessment, as proposed by Ritz et al. (2009), to rank potential indicators for the purpose of monitoring soil biodiversity and ecosystem function across Europe. As further described by Stone et al. (2016) this approach enabled a structured ordering of potential indicators by applying the following steps: (1) establishment of the purpose for which the monitoring will be applied; which in our case was for monitoring changes in soil biodiversity and ecosystem functions across Europe; (2) listing of potential biological indicators, derived from a wide range of sources including literature, past European and national-scale studies included in a meta-analysis (Faber et al., 2013) and a panel of European experts; and (3) classification of indicators into three operational categories, namely: microbial, faunal and functional techniques. The indicators were then ranked in order of their relevance to specific criteria (further described in Faber et al. (2013), albeit with the specific definitions being modified). Indicators needed to be: measurable (related to the availability of the necessary laboratory equipment and technical skills); cost-effective (includes capital and consumable costs as well as the labour intensiveness in the field and the laboratory); policyrelevant (to provide data on biodiversity and ecosystem functions for informed decision making); sensitive to likely changes such as land use and disturbance; and fit for use (meaningful, spatiotemporally relevant, understandable and open to standardisation). An algorithm then calculates an overall ranking score from these individual criteria (see Ritz et al., 2009; Stone et al., 2016). Eighteen potential indicators were thus selected for subsequent evaluation by this ranking procedure, following the tenets of the logical sieve, from the 30 originally considered (Table 1 ).

\subsection{Selection of sites for indicator evaluation}

As the objective was to determine how sensitive the selected indicators are to typical disturbances in the European situation, six sites across Europe were chosen that had: a consistent agricultural management history over several years; were characteristic of recognised European climatic zones; consisted of at least three, independent, replicated plots of two contrasting treatments which varied in intensity of management. Site details are given in Table 2 and summarised here as four arable and two grassland sites: Lusignan, Atlantic arable site in France, with rotations of grassarable (least intensive) and continuous arable (most intensive) (http://www.soere-acbb.com/index.php/fr/, Kunrath et al., 2014; Senapati et al., 2014); Scheyern, Continental arable site in Germany with long-term plots of minimum-tillage with small fertilisation (least intensive) and conventional tillage with large fertilisation (most intensive) as described by Zeitz. et al. (2004); Moskanjci, Pannonian arable site in Slovenia, with long-term plots of minimum-tillage (least intensive) and conventional tillage (most intensive) according to Kaurin et al. (2015); Castro Verde, Mediterranean arable site in Portugal, where the least intensive plots were grass-arable rotation with minimum tillage and no fertilisation and the most intensive plots were conventionally ploughed and fertilised, as described by Marta-Pedroso et al. (2007); Yorkshire Dales, Atlantic grassland site in the UK, with paired plots of extensive and intensive grassland at three locations within the Yorkshire Dales National Park, as described by de Vries et al. (2012); Hainich, Continental grassland site in Germany, with paired plots of extensive and intensive grassland as described by Fischer et al. (2010). 
Table 2

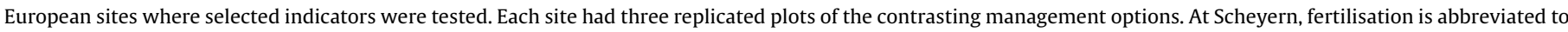
fert.

\begin{tabular}{|c|c|c|c|c|c|}
\hline Climatic zone & Land use & Soil texture & Management & Country & Site name \\
\hline Continental & Arable & Silt Loam & Till, conventional fert vs no-till, minimal fert & Germany & Scheyern \\
\hline Atlantic & Arable & Silt Loam & Arable vs grass/arable & Lusignan & Lusignan \\
\hline Pannonian & Arable & Clay Loam & Till vs no-till & Slovenia & Moskanjci \\
\hline Mediterranean & Arable & Sandy Loam & Cereal vs fallow & Portugal & Castro Verde \\
\hline Continental & Grass & Clay/Silty Clay & Intensive vs extensive & Germany & Hainich \\
\hline Atlantic & Grass & Sandy Silt Loam & Intensive vs extensive & UK & Yorkshire Dales \\
\hline
\end{tabular}

The management options chosen are typical for European soils. The intensity of land use at each site was calculated using the equation of Blüthgen et al. (2012), modified to include time since tillage and tillage depth. Thus:

Land use index $(\mathrm{LUI})=\mathrm{N} /$ mean $+C /$ mean $+L U /$ mean

$$
+5(T / \text { mean })+5(D / \text { mean })
$$

where $N=\mathrm{kg} \mathrm{Nha}^{-1}$ year $^{-1} ; C=$ grass cuts year $^{-1} \times 50$ (to give $\mathrm{C}$ an equivalent weighting to $N, L U, T$ and $D)$ ); $L U=$ livestock units ha $^{-1}$ year $^{-1}$ (grazing intensity); $T=$ days since tillage, converted to a negative exponential scale $\left(T=187.47 \mathrm{e}^{-0.014 x}\right.$, where $x=$ days since tillage) to account for tillage effects being most evident immediately after tillage; $D=$ depth $(\mathrm{cm})$ of tillage; mean = average $(N, C$, $L U, T$ or $D)$ for all plots at all sites; (T/mean) and $(D /$ mean) were multiplied by 5 as a weighting to reflect that the impact of tillage was greater than that of mowing, grazing or fertilisation on soil biological processes.

\subsection{Sampling and standardisation}

The selected indicators chosen for validation required different sampling procedures: with some having to be measured in situ; some requiring intact soil cores; and the rest needing a composite bulk soil sample. Samples were then sent to the various analysing laboratories around Europe, such that each indicator was measured by only one laboratory. A coding system was developed to give each sample a unique identifier, linked to a searchable database designed for long-term data storage of the results collected. For standardisation of sampling, detailed standard operating procedures (SOPs, with step by step instructions and photographs to ensure clarity) and a video of the composite soil sampling were distributed before sampling began (http://www.youtube. $\mathrm{com} /$ watch? $\mathrm{v}=$ =k7BEInBXEc\&feature=youtu.be).

Samples were taken on two occasions at each site, 2012 (autumn) and 2013 (spring or autumn), to ensure at least a minimum temporal variation, and included the in situ measurements, intact cores and composite soil samples as outlined above. Sampling followed a prescribed pattern within an $8 \mathrm{~m} \times 8 \mathrm{~m}$ area selected at a random location in each replicate plot (Fig. 1). Within each sampling area there was: a composite soil sample prepared by mixing five soil samples taken by auger from the top $15 \mathrm{~cm}$, this consisted of soil from a central auger and then four more augers $1 \mathrm{~m}$ away from the central point in North-South and East-West directions; five intact soil cores ( $5 \mathrm{~cm}$ diameter and $5 \mathrm{~cm}$ deep) were each collected for separate microarthropod and enchytraeid extraction (ISO 23611-2, 2006; ISO 23611-3, 2007), three soil pits of $35 \mathrm{~cm} \times 35 \mathrm{~cm}$ (the depth varied according to the site conditions, but it was always between 10 and $20 \mathrm{~cm}$ ) were dug for the hand-sorting and formaldehyde extraction of earthworms (ISO 23611-1,2006), with collected earthworms being preserved in 70\% ethanol in the field; bait lamina sticks were laid out in five blocks within each area (ISO 18311, 2012); water infiltration was determined using a double ring infiltrometer (DIN 19682-7, 2007). In the field, composite soil samples and intact soil cores were kept in an

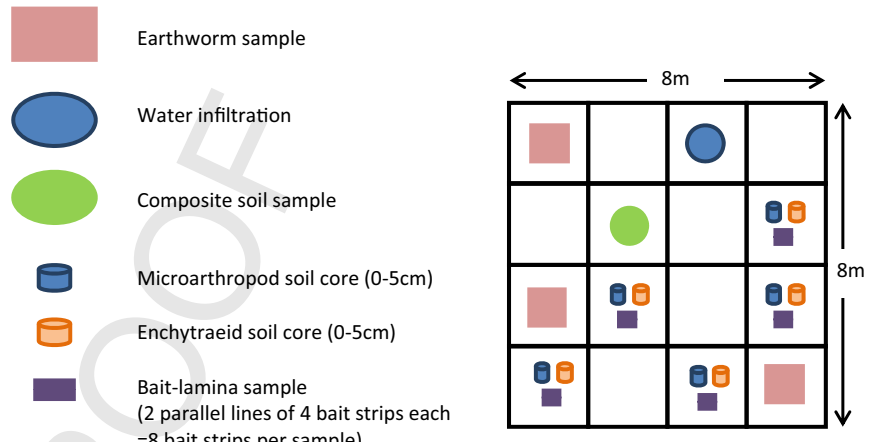

Fig. 1. Sampling plan for each of the indicator sites. This common plan was implemented across all six sites in both sampling years.

insulated box containing frozen 'cool blocks' until they could be stored at $4{ }^{\circ} \mathrm{C}$ in a laboratory. The composite soil samples were sieved through a $4 \mathrm{~mm}$ diameter mesh and divided into aliquots appropriate for the different soil analyses. Aliquots of composite soil and intact soil cores were repackaged in insulated boxes with frozen 'cool blocks' and dispatched by $24 \mathrm{~h}$ courier to the analysing laboratories.

\subsection{Laboratory analysis}

Soil from the composite samples was analysed as follows: DNA was extracted (ISO 11063; Petric et al., 2011) and DNA yield quantified (Plassart et al., 2012). Extracted DNA was used to determine the structure of the microbial community by terminal restriction fragment length polymorphism of the archaeal, bacterial and fungal communities (TRFLP, Plassart et al., 2012), and also for quantitative PCR to determine abundances of the total bacterial community (16S rRNA) and of functional genes involved in nitrogen cycling by using the amoA, nirK, nirS and nosZ1 genes as molecular markers (Bru et al., 2011). Ergosterol was quantified following alkaline extraction (de Ridder-Duine et al., 2006); Multiple substrate utilisation with MicroResp (Campbell et al., 2003, as modified by Creamer et al., 2009) used eight substrates: water, L-arginine, L-malic acid, gamma amino butyric acid, $n$-acetyl glucosamine, $\mathrm{D}(+)$ glucose, alpha ketogluterate and citric acid; extra-cellular enzyme activity (EEA; Johansen et al., 2005; Hendriksen et al., 2015) from the activity of $\beta$-1,4-glucosidase and cellobiohydrolase, $\alpha$-1,4-glucosidase, $\beta$ - $N$-acetyl-glucosaminidase, $\beta$-1,4-xylosidase, aminopeptidase, phosphatase and arylsulphatase; Nematodes, which were extracted by an Oostenbrink elutriation and Baermann funnel technique from $100 \mathrm{~g}$ of fresh soil for directed-T-RFLP analysis (Donn et al., 2012); potentially mineralisable nitrogen (PMN, Canali and Benedetti, 2006); hot water extractable carbon (HWC, Ghani et al., 2003); Microbial resilience to antibiotic (resilience) was determined in 96 well micro-titre plates as the difference in the lag-phase until growth of bacteria from a suspension of composite soil either with or without penicillin. We used six replicates of $200 \mu \mathrm{l}$ of soil suspension ( $1.5 \mathrm{~g}$ dry weight equivalent soil $100 \mathrm{ml}^{-1}$ Neff's modified amoeba saline (Page, 1988)) added to $200 \mu \mathrm{l}$ of $1 / 10$

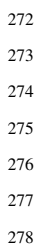

279 
strength Luria-Bertani medium either with $15 \mu \mathrm{g}$ penicillin well ${ }^{-1}$ (Penicillin from AppliChem, BioChemica, Penicillin G-Kaliumsalz) or without penicillin, incubated at $20^{\circ} \mathrm{C}$ and the optical density $(450 \mathrm{~nm})$ measured every $1 \mathrm{~h}$ for $72 \mathrm{~h}$ with automatic agitation for $5 \mathrm{~s}$ prior to reading; potential nitrification (Kandeler, 1996, adapted to microplate reader as described by Sousa et al., 2004); phospholipid fatty acid (PLFA) determinations were based on the guideline ISO/DTS 29843-2 (2011). The method proposed in this SOP results from a modification of the ISO guideline, including a second method for fatty acid identification (Francisco et al., 2015). Earthworms were counted, adults identified to species and juveniles to genus, and then weighed. Soil physical and chemical determinations were performed by the Soil Analysis Laboratory of INRA in Arras, France, which is accredited for soil and sludge analysis.

Soil from intact cores ( $5 \mathrm{~cm}$ diameter) was used to extract enchytraeids and microarthropods. Enchytraeids were extracted with O'Connor's hot/wet funnel method (O'Connor, 1962) (ISO 23611$3,2006)$. Specimens were identified to species using the keys and techniques of Schmelz and Collado $(2010,2012)$, together with primary literature. Microarthropod extraction followed ISO 23611-2 (2004) using a Macfadyen high gradient extractor for 7 days, slide mounted and identified to species.

\subsection{Statistical analysis}

Data for individual measures were checked for homogeneity of variances and were transformed to ensure a normal distribution for analysis. Abundances of enchytraeids and microarthropods were converted to natural logarithms, while an angular transformation was used for percent composition data. All analyses were performed using Genstat 14th edition. Univariate data were analysed by two-way ANOVA while bait lamina data were analysed as a factorial ANOVA, using the mean feeding activity per plot and depth and making a comparison between depth distribution and treatment. Multivariate data [i.e. T-RFLP (bacteria, archaea, fungi and nematodes analysed separately), PLFA, EEA, MicroResp] were analysed using principal component analysis (sums of squares and products) and the resulting principal component (PC) scores treated as univariate data. Shannon and inverted-Simpson were calculated as diversity indices for: microbial T-RFLP, mites, enchytraeids and earthworms.

For the global data across all sites, the univariate data were analysed by ANOVA using site, management and year as the factors. For specific site effects, because the management was specific to each site, the ANOVA analysis was run comparing control and treatment at each individual site using treatment and year as the factors. A global multivariate analysis was run, as above, with: hot water extractable C; potentially mineralisable N; Ergosterol; molecular biomass; $16 \mathrm{~S}$ rRNA, amoA from bacteria (AOB) and archaea (AOA), nirK, nirS and nosZ1 gene abundances; enchytraeid abundance; enchytraeid diversity (inverse Simpson); earthworm abundance; earthworm diversity (inverse Simpson); mite abundance; mite diversity (inverted Simpson); resilience; nitrification; nematode PC1; nematode PC2; PLFA PC1; PLFA PC2; MicroResp PC1; MicroResp PC2; EEA PC1; EEA PC2; T-RFLP PC1; T-RFLP PC2 (T-RFLP PCs calculated separately for bacteria, archaea and fungi).

\subsection{Relative costs of analysis}

The costs associated with each indicator were estimated on a relative basis for the three areas of: (1) operation in the field; (2) operation in the laboratory; and (3) equipment/instrumentation. On each sampling occasion the field teams recorded the personhours required for each task. The laboratory analytical teams then made observations on the ease of running each assay, the throughput (samples per unit time) and whether the assay yielded multiple or single endpoints. Finally, the capital costs of the main instruments used in each assay were noted. The methods were then ranked under each category for comparison.

\section{Results}

\subsection{Selection of indicators}

The result of the selection process based on a logical sieve was a weighted score for each of the 27 potential indicators (Table 1). Most of the higher-ranking indicators were taken forward for evaluation (Table 1), but some of them were not considered because of methodological or practical limitations. For example, the molecular methods for faunal indicators were only considered advanced enough for nematodes (Vervoort et al., 2012). Litter bags and bait lamina (with a logical sieve score of 500 and 492, respectively) were statistically indistinguishable and logistical considerations favoured the bait lamina assay. Protistan morphology was considered too laborious and specialist, while the other low-scoring potential indicators were considered inappropriate or duplicated by higher scoring indicators. Some low-scoring potential indicators were evaluated, such as water infiltration because of its direct relevance to the key ecosystem service of water retention. Basal respiration was not evaluated independently but could be inferred from the MicroResp assay using the substrate 'water'. Although denitrification is an important component of the nitrogen cycle, determination is complicated by the partitioning between end products $\left(\mathrm{N}_{2} \mathrm{O}\right.$ and $\left.\mathrm{N}_{2}\right)$ and is better represented by the functional gene assay (see for example Wessén et al., 2011). The choice between pyrosequencing (or other new sequencing technologies) and T-RFLP is discussed below, while chip and other 'omic' technologies are currently too expensive and technically demanding for routine monitoring purposes. A rapid indicator for microbial resilience to antibiotic, estimated as growth in the presence of penicillin, was developed and tested.

\subsection{Indicator performance across all sites}

The land use intensity (LUI) at each site (Table 3), and especially the difference in LUI between the differently managed plots, provides a means of comparing the intensity of the management options at different sites. Thus, the arable sites (Castro Verde, Lusignan, Moskanjci, Scheyern) had greater average LUIs (5.4, 12.4, 18.4 and 25.4 respectively) than the grassland sites (Hainich and Yorkshire Dales, 5.2 and 1.2 respectively). The arable sites also generally had the greatest differences in LUI (Table 3), an exception being at Lusignan where there was no difference in LUI because of the incorporation of a grass ley in the arable rotation had been imposed three years earlier, and so for the last three years the two management options had received exactly the same treatment.

Some of the indicators, namely bait-lamina and water infiltration, could not be used across all sites because of logistical constraints. The bait-lamina test requires the sticks with substrate to remain in situ for several weeks, depending on the climatic conditions and biological activity at the field site, which was not always compatible with the field operations for actively managed arable sites. The method used for water infiltration needs a large volume of water (up to $200 \mathrm{~L}$ per individual determination) and can take more than $2 \mathrm{~h}$ for a single determination, so for sites remote from water sources this was simply not practical.

All indicators were sensitive to site (i.e. the sites could be differentiated on the response of the indicators). A principal component analysis of all data (Fig. 2) showed that the grassland sites (Yorkshire Dales and Hainich) clustered together in the PC3-PC4 plot 
Table 3

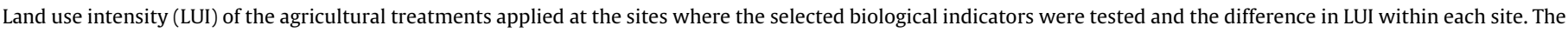
treatments are either control $(\mathrm{C})$, least intensive management at that site, or treatment $(\mathrm{T})$, the most intensive treatment at that site.

\begin{tabular}{|c|c|c|c|c|c|c|c|}
\hline Site & Land use & & Treatments & Climatic zone & Country & LUI & Difference \\
\hline Scheyern & Arable & $\begin{array}{l}\mathrm{C} \\
\mathrm{T}\end{array}$ & $\begin{array}{l}\text { Organic } \\
\text { Conventional }\end{array}$ & Continental & Germany & $\begin{array}{l}15.4 \\
35.4\end{array}$ & 20.0 \\
\hline Moskanjci & Arable & $\begin{array}{l}\mathrm{C} \\
\mathrm{T}\end{array}$ & $\begin{array}{l}\text { Minimum tillage } \\
\text { Conventional tillage }\end{array}$ & Pannonian & Slovenia & $\begin{array}{l}14.8 \\
22.1\end{array}$ & 7.3 \\
\hline $\begin{array}{l}\text { Castro } \\
\text { Verde }\end{array}$ & Arable & $\begin{array}{l}\mathrm{C} \\
\mathrm{T}\end{array}$ & $\begin{array}{l}2 \text { year fallow after arable } \\
\text { Conventional tillage }\end{array}$ & Mediterranean & Portugal & $\begin{array}{r}0.1 \\
10.8\end{array}$ & 10.7 \\
\hline Lusignan & Arable & $\begin{array}{l}\mathrm{C} \\
\mathrm{T}\end{array}$ & $\begin{array}{l}\text { Continuous arable } \\
3 \text { years arable after pasture }\end{array}$ & Atlantic & France & $\begin{array}{l}12.4 \\
12.4\end{array}$ & 0.0 \\
\hline Hainich & Grass & $\begin{array}{l}\mathrm{C} \\
\mathrm{T}\end{array}$ & $\begin{array}{l}\text { Extensive grass (species rich) } \\
\text { Intensive grass (fertilised) }\end{array}$ & Continental & Germany & $\begin{array}{l}3.0 \\
7.6\end{array}$ & 4.5 \\
\hline $\begin{array}{l}\text { Yorkshire } \\
\text { Dales }\end{array}$ & Grass & $\begin{array}{l}\mathrm{C} \\
\mathrm{T}\end{array}$ & $\begin{array}{l}\text { Extensive grass (species rich) } \\
\text { Intensive grass (fertilised) }\end{array}$ & Atlantic & UK & $\begin{array}{l}0.4 \\
2.0\end{array}$ & 1.6 \\
\hline
\end{tabular}

explaining $16 \%$ of variation and separately from the arable sites which formed a separate cluster. Sites were different from one another according to the principal component analysis using all the data, but also by analysis of individual indicators. For example: indicators that separated the Yorkshire Dales from Hainich were: MicroResp; enchytraeids; AOB; 16S; nosZ1; AOB; PMN; ergosterol; soil water content; nitrification; and T-RFLP (archaeal, bacterial and fungal). Lusignan gave a significantly different response than Moskanjci to: EEA; AOB; NirS; resilience; nitrification; and T-RFLP (archaeal, bacterial and fungal) (Supplementary Tables S1 and S2). Measures of biodiversity, although showing significant differences between sites, were idiosyncratic (Supplementary table* S1). Thus, for example: using enchytraeid H' the Yorkshire Dales and Hainich sites were more diverse than Moskanjci and Scheyern; with earthworm H' Yorkshire Dales was equally as diverse as Moskanjci and Scheyern but Hainich was less diverse; with mite H' Scheyern was the least diverse site. The grassland sites, Yorkshire Dales and Hainich, had the greatest faunal diversity with Castro Verede and Scheyern having the least. Microbial biodiversity as determined from T-RFLP was also idiosyncratic, but showed that Yorkshire Dales had the greatest biodiversity of archaea while Moskanjci tended to have a large biodiversity of bacteria and fungi.

\subsection{Indicator performance at individual sites}

The effects of management at the individual sites could be distinguished by a range of indicators, albeit a different set of indicators at each site (Table 4). In general, as the difference in LUI increased so the number of indicators showing an effect of the management increased, with the exception of Scheyern which had the greatest difference in LUI (20), yet the conventionally managed plots were only differentiated from the organically managed plots by four of the indicators used, namely resilience, bait lamina, earthworms and enchytraeids (Table 4). This was the same number of differentiating indicators as at the sites with the lowest LUI, i.e. Lusignan and Yorkshire Dales. At Lusignan there were no management effects detected by the functional indicators, although we were not able to use the bait lamina method there, and at Scheyern no management effects were detected by the microbial indicators (Table 4). Water infiltration was only measured at Moskanjci, Scheyern, Castro Verde and Lusignan in 2012 and rates were only significantly different at Scheyern between the organically managed $\left(24 \mathrm{~mm} \mathrm{~h}^{-1}\right)$ and conventionally managed $\left(506 \mathrm{~mm} \mathrm{~h}^{-1}, P<0.01\right)$ plots. Differences due to management were not significant at the other sites in autumn 2012 but water infiltration did differ between sites. Thus infiltration rates for least intensive and most intensive plots (respectively) were at: Moskanjci 1.4 and $1.9 \mathrm{~mm} \mathrm{~h}^{-1}$; Castro Verde 0.44 and $0.39 \mathrm{~mm} \mathrm{~h}^{-1}$; and Lusignan 130 and $202 \mathrm{~mm} \mathrm{~h}^{-1}$.
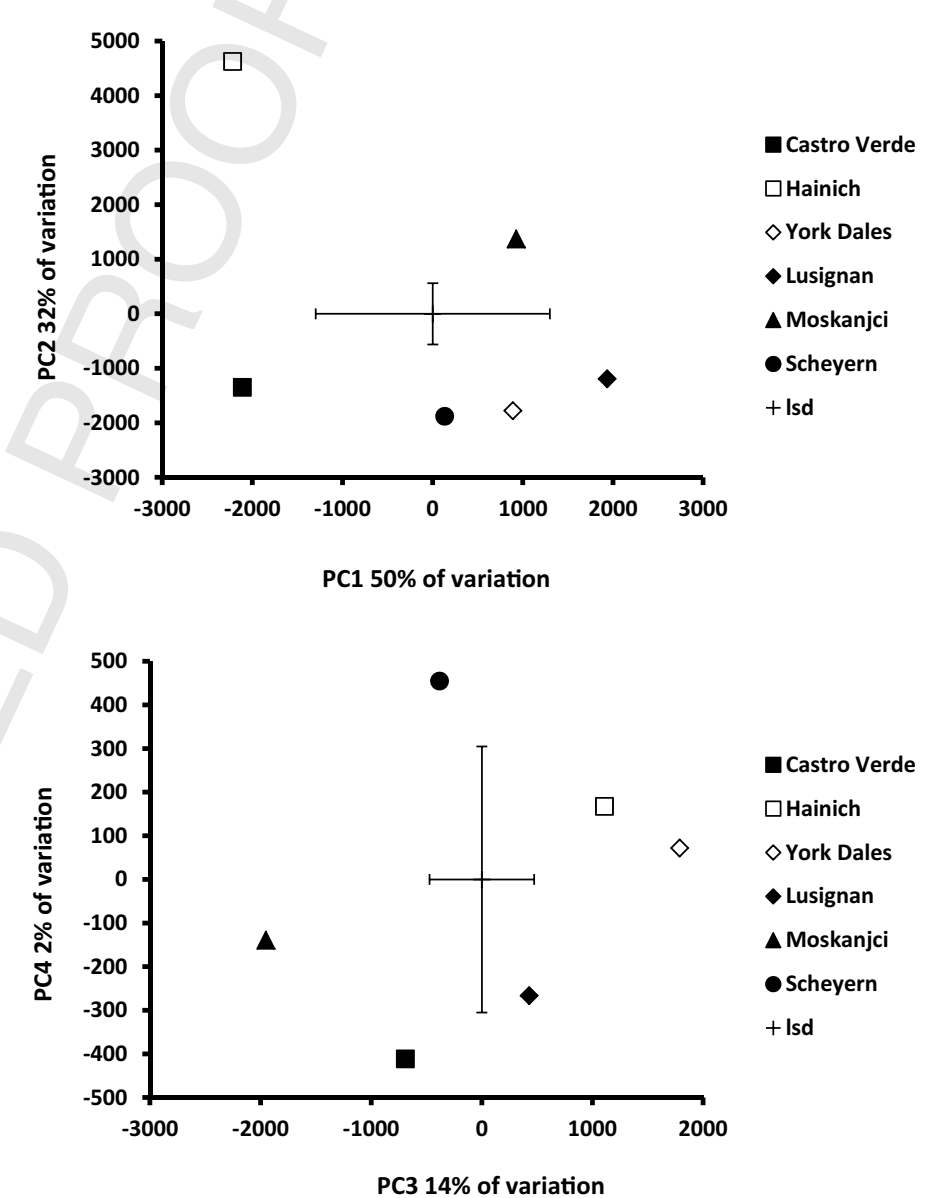

Fig. 2. Mean scores, and percentage variance accounted for, of the first four principal components (PC) from analysis of all the indicator results, over both sampling occasions and treatments, for each site. Bar represents the least significant difference (LSD, $P<0.05)$.

The indicators of biodiversity also responded differently to the treatments at each site with: enchytraeid H' differentiating treatment and control plots at Castro Verde, Hainich and Scheyern; earthworm H' only differentiating at Lusignan; mite H' only differentiating at Moskanjci; and microbial T-RFLP differentiating at Castro Verde, Hainich and Yorkshire Dales.

\subsection{Relative indicator costs}

Table 5 shows the groupings of the indicators and within each column the first group scores best for that attribute. For 'ease of field work', the 'easy' group of indicators required a composite soil 
Table 4

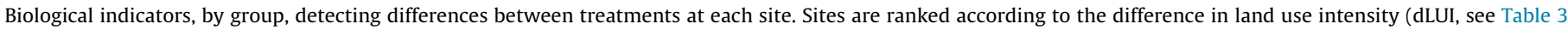

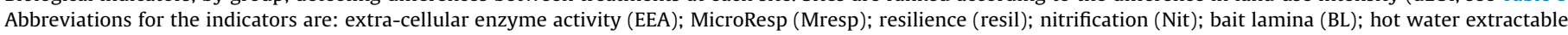

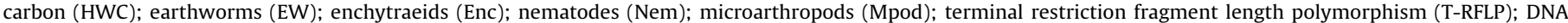
abundance (DNA). bait lamina (BL) tests could not be used at Lusignan and Hainich (x).

\begin{tabular}{|c|c|c|c|c|c|c|c|c|c|c|c|c|c|c|}
\hline \multirow{2}{*}{$\begin{array}{l}\text { Site } \\
\text { Lusignan }\end{array}$} & \multirow{2}{*}{$\begin{array}{l}\text { dLUI } \\
0.0\end{array}$} & \multicolumn{6}{|c|}{ Functional } & \multicolumn{4}{|c|}{ Faunal } & \multicolumn{3}{|c|}{ Microbial } \\
\hline & & & & & & $\mathrm{x}$ & & EW & & Nem & & T-RFLP & DNA & \\
\hline $\begin{array}{l}\text { Yorkshire } \\
\text { Dales }\end{array}$ & 1.6 & & & Resil & & $\mathrm{BL}$ & & & & & Mpod & T-RFLP & & FG \\
\hline Hainich & 4.5 & EEA & Mresp & & Nit & $\mathrm{x}$ & & EW & Enc & & & T-RFLP & & FG \\
\hline Moskanjci & 7.3 & & Mresp & & Nit & $\mathrm{BL}$ & HWC & EW & Enc & Nem & Mpod & T-RFLP & DNA & FG \\
\hline Castro Verde & 10.7 & EEA & Mresp & Resil & Nit & $\mathrm{BL}$ & & EW & Enc & Nem & & T-RFLP & & \\
\hline Scheyern & 20.0 & & & Resil & & $\mathrm{BL}$ & & EW & Enc & & & & & \\
\hline
\end{tabular}

\section{Table 5}

Relative cost-effectiveness of the selected indicators, grouped according to: ease of collecting soil samples from the field (three categories, 1 - easy; 2 - moderate; 3 - difficult); utility in terms of getting more than one piece of information from the test ( 1 - single endpoint, 2 - multiple endpoint); ease of laboratory operations or skill-level required for operation (1 - basic skill level; 2 - moderate; 3 technically demanding); potential laboratory throughput of samples ( 1 - high; 2 - low); capital costs to set up analysis from new ( 1 - least expensive, 2 - moderately expensive, 3 - most expensive). Indicators are abbreviated as in Table 1 apart from: DNA abundance (DNA) and resilience (resil). Indicators are listed alphabetically and not ranked within categories.

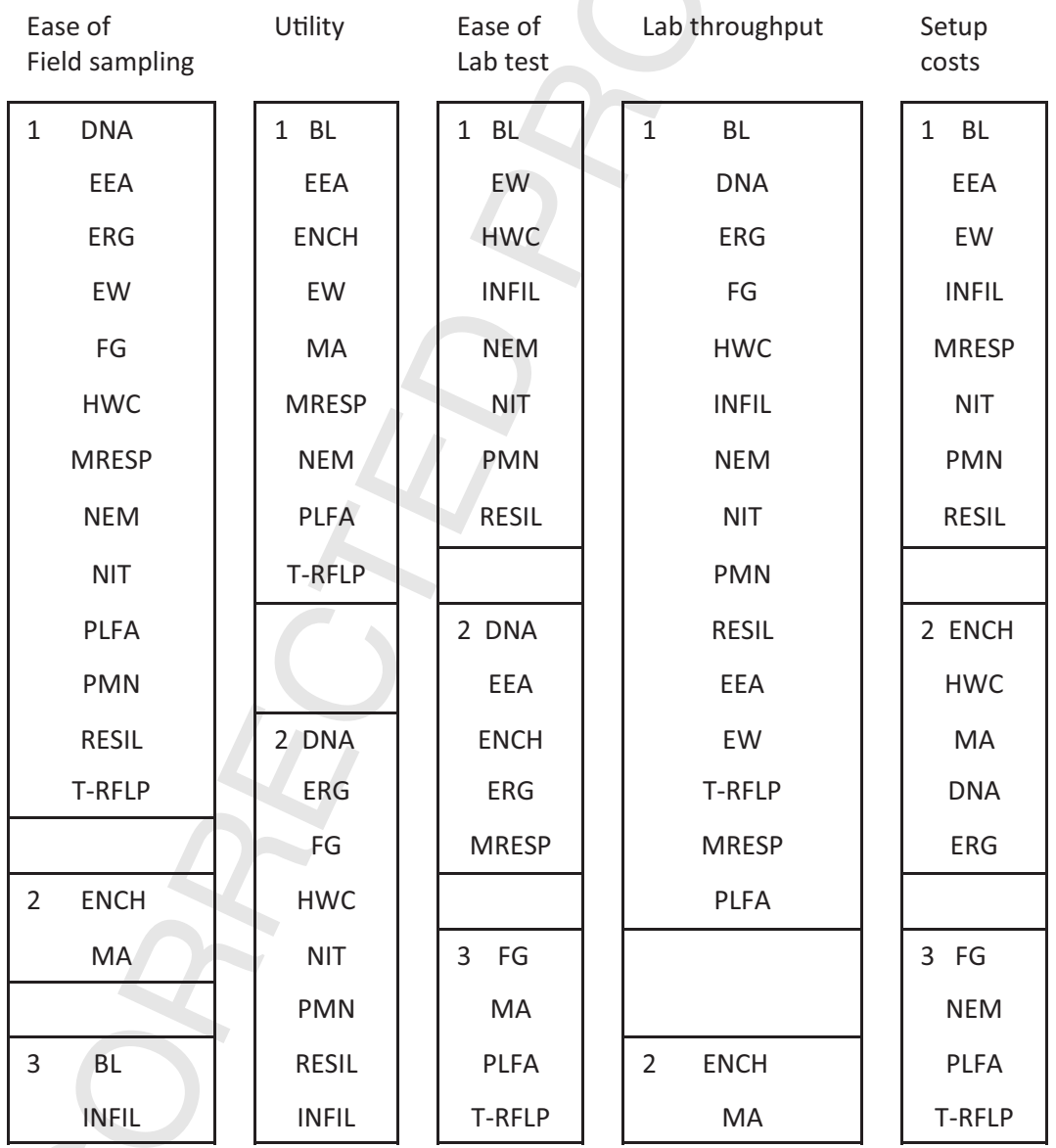

sample that could be readily collected within a single day, the 'moderate' group could also be collected in a single day by a single visit to each site but sampling was more involved than the composite soil, while in the 'difficult' group the bait lamina assay required revisiting the site at a variable time later (i.e. when about 50\% of the substrate has been eaten) and the water infiltration assay required that a large volume of water be readily available and took more than a single day at some sites. The 'utility of the assay' grouped those indicators that gave several endpoints (i.e. EEA and MicroResp assayed eight substrates simultaneously; faunal groups give information on biodiversity, organisms abundance/biomass and functional attributes; PLFA informs on microbial biomass, bacterial: fungal ratio and indicator peaks) and grouped those that only give a single endpoint. The 'ease of laboratory assay' had three groups, the 'basic skill level' group containing indicators requiring a simple incubation and/or extraction (nitrification for example requires a single extraction with a salt solution), a 'moderate' group requiring a more complex extraction or setup (thus DNA or ergosterol need a sequential extraction), and a 'technically demanding' group requiring the most sophisticated extractions and analysis (such as TRFLP which needs additional processing once the DNA has been extracted). The 'laboratory throughput' gave a 'high' and 
a 'low' group according to the rate and number of samples that can be handled at any one time. Finally the 'setup cost' ranked the indicators in three groups as the 'least expensive', which tend to be incubations whose endpoint is determined by colorimetric reaction, through the 'moderately expensive' to the 'most expensive' techniques which need gas chromatographs and nucleic acid sequencers with a relatively high associated capital and consumable cost. The table of relative costs was broken down into these different scenarios, mainly because most laboratories would be starting out with different amounts of essential equipment in place. So start-up costs would be different in each case.

\section{Discussion}

The objective of the study was to recommend indicators for soil biodiversity and ecosystem function. Although samples were collected from European agricultural sites, the outcomes would be relevant for non-agricultural soils, especially those of a mineral or organo-mineral texture. A breakdown of the cost effectiveness of the indicators showed the expected trade-off between the intensity of work in the field and intensity in the laboratory. Thus, earthworms and water infiltration, which are labour intensive in the field, require relatively little laboratory time, while DNA based analyses from the easily obtained composite soil sample require the most laboratory effort.

An indicator programme should be based upon a suite of different indicators, as shown by the fact that none of the indicators were able to detect all management effects across all sites, to enhance reliability. However a balance between reliability (larger set of indicators) and costs (smaller set of indicators) is always at stake, during the design of any monitoring system. The ENVASSO project (Bispo et al., 2009), which was carried out to propose a set of suitable indicators for monitoring the decline in soil biodiversity, selected indicators both from a literature review and an inventory of national monitoring programmes. ENVASSO recommended indicators in a different way by having a tiered approach, with Level I being done at all times, Level II at times relevant for specific issues or if resources were available and Level III was optional. ENVASSO also recommended separate indicators for biodiversity (Level I = earthworm species, or enchytraeids at sites with acid soils, and Collembola species; Level II = macrofauna, mites, nematodes, bacteria and fungi, Level III = protists and faunal activity from litter bags or bait lamina) and function (Level I = basal respiration, Level II = bacterial and fungal activity, Level III = faunal activity).

For monitoring under the European climatic zones and land uses we also suggest different indicators of ecosystem function than for monitoring of soil biodiversity. For ecosystem functions related to the services of water regulation, C-sequestration and nutrient provision (which are all carried out by the general biological community), we would recommend at least three of the selected indicators, one from each group (faunal, microbial and functional), which would be earthworms, functional genes and bait lamina based on the results given in Table 4. In any monitoring scheme there will be over-riding considerations of resources, time and expertise available, so any decision to apply extra tiers, further indicators or more complete datasets then becomes an internal matter that is different for each monitoring scheme. For diversity, our results showed that diversity of the microbial and faunal groups responded differently to the changes in land use intensity and that their ranking of biodiversity varied between sites (Supplementary table* S1). For example, sites such as the Yorkshire Dales had a consistent increase in diversity (Shannon) in the least intensive management for earthworms, mites, Collembola and archaea but not for enchytraeids, bacteria and fungi. Other sites had contrasting trends, such as Moskanjci which had greater earthworm diversity but less enchytraeid diversity in the least intensive management, or Lusignan which had greater earthworm and archaeal diversity but less enchytraeid and bacteria diversity in the least intensive management (Table S1). For effective monitoring of biodiversity, therefore, all taxonomic groups would need to be addressed because changes in the biodiversity of one group cannot be used to infer changes in other taxonomic groups.

These bioindicators will require standardisation and their deployment will need to be cost-effective and policy-relevant in order to be efficiently applied throughout Europe. This will allow us to identify the land uses which have the most severe impact on soil functioning and to quantify threats to soil ecosystem functions.

\subsection{Indicator selection}

The logical sieve (Ritz et al., 2009; Stone et al., 2016) based approach that we used is considered to be a scientifically valid and objective selection process that has been used in similar scientific studies for indicator selection in the face of a large number of methods to choose from (Aalders et al., 2009). The scores from this method can then inform judicial selection of the indicators, because this process resulted in several indicators ending up with similar scores. For example, basal respiration, bait lamina and litter bags all scored around 500, so we chose between these equivalent indicators based on the availability of equipment and expertise in the participating laboratories. In other cases, some indicators that scored relatively poorly but had high relevance to the ecosystem services of interest were included, for example water infiltration (which had a score of 398) which is highly relevant for water regulation. The scores for the faunal indicators were all similar with no real difference between the scores for molecular analysis and morphological analysis. This is probably because the molecular methods for fauna provide information on the same targeted endpoint, i.e. the composition of the specific faunal group. So they are different methods, but aiming at the same result. The equivalence of scores may also reflect the fact that molecular methods for faunal analysis are not yet commonplace and so the advantages in higher throughput have not fully been appreciated (Thompson and Newmaster, 2014). The possibility of metabarcoding, which will allow identification of all faunal groups simultaneously (Creer et al., 2010; Taberlet et al., 2012) is only beginning to be explored for soil systems, so we believe that molecular methods for faunal indicators will become increasingly preferred. In contrast, some of the molecular methods for microbial analysis were the least favoured. This may result from several factors, including the fact that the output represents new information (i.e. unlike the molecular faunal methods you do not get the same information as existing methods such as T-RFLP and PLFA) and so the interpretation is less straightforward. Faunal analysis has traditionally been based on a list of species (i.e. Bongers, 1990) so the developing faunal molecular methods speed up and simplify the process of acquiring the list of species (sequences). This approach was not widespread in the study of microbial ecology, or relied on cultivation based techniques, and the equivalent associations between microbial taxa and traits is an emerging science (Fierer et al., 2014). There is also the fact that developments in molecular technology are moving so rapidly that standardisation maybe considered premature. We acknowledge that the new sequencing technologies such as the Illumina or Ion torrent platforms are becoming cheaper, which would provide more information on the specific indicator taxa responding to land use change. However we note they are still not as cost effective as T-RFLP assays and, for detecting change at the community level at least, there are currently few advantages in applying sequencing over T-RFLP (Thomson et al., 2015).

Most of the non-molecular methods selected for testing are already in use in monitoring schemes from individual 
European countries (Turbé et al., 2010; Pulleman et al., 2012; Faber et al., 2013). As such these methods have undergone thorough scientific validation and their usefulness as indicators has been demonstrated. There was little difference between the functional indicators as those receiving the lowest score (water infiltration and MicroResp) still received $80 \%$ of the score of the highest scoring (nitrification). This could be a reflection that functional methods have been effectively evaluated in previous monitoring schemes (Faber et al., 2013) and generally have a proven track record for all aspects of the logical sieve approach. This study also tested methods not currently used as indicators across Europe. We focused on functional genes for nitrogen cycling because previous studies showed that they were good candidate bioindicators for soil monitoring and are increasingly common in the scientific literature (Ritz et al., 2009; Wessén and Hallin, 2011; Jones et al., 2014). Bait lamina (Van Gestel et al., 2003) and water infiltration (Tejedor et al., 2013) have been used previously and standardised methods (ISO 18311, 2014 and DIN 19682-7:2007-07, respectively) already exist, but they have not been widely used in European monitoring schemes. Our experience suggested that water infiltration was too timeconsuming and logistically demanding, given that it required an abundant and easily available water supply to be practical for monitoring. Although there were constraints to using bait lamina sticks at some of our sites (cultivation occurring too soon after deployment), its ease of use, functional relevance (Römbke, 2014), and sensitivity led us to recommend its use. MicroResp and extracellular enzyme activity (EEA) are developments of the multi-substrate assay approach and comparable to methods such as BIOLOG that can also be used as biological indicators of soil quality (Rutgers et al., 2006). The resilience assay (microbial resilience to antibiotic) was the only truly novel method tested in this study and, although it proved to be a straightforward assay with high-throughput, results would need to be tested for relevance to ecosystem functions in more detail. Here we chose to analyse the lag phase of the growth curve because the initial biomass differences between samples is more likely to influence the subsequent exponential growth. Also, certain fast growing microbes are likely to benefit proportionally more than others which will be especially pronounced in later growth phases, and in nutrient rich media total abundances eventually often merge as the closed systems have limited carrying capacities. The analysis of other growth parameters could be explored. These methods were included because of their relevance to soil biodiversity and ecosystem function.

\subsection{Indicator performance}

We used a variety of management treatments, typical of European practice, to ascertain the capabilities of the selected indicators. The indicators selected clearly distinguished between the different field sites, which gives a measure of confidence that the indicators selected are valid to include in a European wide survey. The samples did not include examples of forest soil, nor organic-matter rich soils. To extend the analyses to these systems or soil types would have required some of the methodology to be modified, for example it would have been impractical to rely on earthworm diversity and abundance as they are rare in acid or highly organic soils (Petersen and Luxton, 1982; Lavelle and Spain, 2005) and DNA and other chemical extractions from humic-rich soils would require different protocols (Miao et al., 2014). Although the equation used to calculate land use intensity was originally developed for grassland (Blüthgen et al., 2012), our modification of this calculation provided a means to compare the sites used in this study objectively as they also included non-grassland. At the Lusignan site, where the transition from grass to arable took place three years before sampling, the LUI equation calculated no difference in intensity between the control (grass - arable) and treatment (continuous arable) plots. The treatments were obviously very similar given the minor changes observed but earthworms may have been responding to the extra organic matter incorporated from the grass, even after three years (Van Eekeren et al., 2008). The effects the grass phase of the rotation maybe equivalent to small additions of fertiliser, as at the Yorkshire Dales site where earthworm biomass in the fertilised plots $\left(67 \mathrm{~g} \mathrm{~m}^{-2}\right)$ was greater than in the unfertilised plots $\left(37 \mathrm{~g} \mathrm{~m}^{-2}\right)$ although this effect was not significant $(P=0.06)$. The LUI at Scheyern did not match the indicator results, fewer of which responded than at Moskanjci which also had differences in tillage intensity as the treatment. In fact the Scheyern site used no-till which might be expected to lead to bigger differences from normally tilled plots than minimum or conservation tillage (Van Capelle et al., 2012).

Some indicators did not respond to the treatments at the test sites (no difference between control and treatment), i.e. abundance of epigeic enchytraeids, diversity of endogeic earthworms, number of earthworm species, potentially mineralisable nitrogen, fungal biomass measured by ergosterol, and the abundance of $16 \mathrm{~S}$ and NirK functional genes. This might be the consequence of not sampling the complete suite of land uses, texture types, other soil characteristics, climate zones, and soil management intensities across Europe. All indicators will probably demonstrate sensitivity in some situations that we did not include in our sampling design. It is likely that earthworms at the sites studied are represented by too few species to be a reliable indicator of biodiversity, although the presence of anecic species is strongly related to water infiltration (Spurgeon et al., 2013; Fischer et al., 2014). Enchytraeids did prove to be a good indicator of biodiversity, but the abundance of epigeic species was more variable than that of the other enchytraeid groups. The abundance of functional genes was normalised (gene copy number per ng of DNA), which could explain why some were less discriminatory.

With the biodiversity indicators a better coverage of changes was given from examination of both microbial and faunal groups. The application of metabarcoding approaches (Fierer et al., 2014) has become more prominent, so that the diversity of the major faunal groups might be determinable from the same sample as used for microbial groups in the near future. For instance, recent developments in the measurement of environmental DNA (e-DNA, Taberlet et al., 2012; Wilcox et al., 2013; Bohmann et al., 2014), would greatly increase the ease of determining faunal communities using DNA-based approaches.

\section{Conclusion}

For undertaking a large-scale biological indicator programme this study has shown that standardisation of methods is an absolute necessity, otherwise it is not possible to properly compare results. This would include an inter-laboratory comparison for the small number of indicators finally selected (i.e. Creamer et al., 2009). It would also necessitate accurate prescription of sampling appropriate for the land uses and edaphic conditions within the monitoring area. An easily accessible database needs to be established to detect temporal changes, so that the results can show a trajectory of system improvement or decline rather than just being a point measure of status. A suite of complementary indicators is necessary, ideally linking biodiversity to soil functioning to give a more meaningful outcome. The ongoing developments in nucleic acid based analyses of biodiversity are likely to improve the throughput and resolution of biodiversity indicators, which need to cover both microbial and faunal groups. Indicators for ecosystem functions related to the services of water regulation, C-sequestration and nutrient provision would include a minimum suite of: earthworms; microbial functional genes; and bait lamina. 


\section{Uncited references}

Philippot et al. (2009) and Tardy et al. (2015).

\section{Acknowledgements}

This research was supported by the European Commission within the project EcoFINDERS (Ecological Function and Biodiversity Indicators in European Soils, FP7-264465, http://eusoils.jrc. ec.europa.eu/projects/ecofinders/); The Scottish Government Rural and Environment, Science and Analytical Services Division; The Portuguese "Liga para a Proteção da Natureza - LPN". The Hainich sites were selected in collaboration with the priority programme 1374 Biodiversity Exploratories of the German Research Foundation (DFG). For support in selecting sites, field sampling and issuing permits we thank Ingo Schöning, Katrin Hartwich, and Christiane Fischer and Steffen Both. We thank the steering committee of the Biodiversity Exploratories, Markus Fischer, François Buscot, Eduard Linsenmair, Ernst-Detlef Schulze, and Wolfgang W. Weisser for the collaboration agreement. Field work permits were issued by the responsible state environmental office of Thüringen, Germany. Sampling at the Scheyern site was strongly supported by the team of the Helmholtz Center Munich (Institute for Soil Ecology), namely Dr. Karin Pritsch and Mr. Georg Gerl. Tina Thane and Jasmin Drägestein are thanked for technical assistance. We thank the anonymous reviewers for insightful comments.

\section{Appendix A. Supplementary data}

Supplementary data associated with this article can be found, in the online version, at http://dx.doi.org/10.1016/j.ecolind.2016. 04.023.

\section{$790 \quad$ References}

Aalders, I., Hough, R.L., Towers, W., Black, H.I.J., Ball, B.C., Griffiths, B.S., Hopkins, D.W., Lilly, A., McKenzie, B.M., Rees, R.M., Sinclair, A.S., Watson, C., Campbell, C.D., 2009. Considerations for Scottish soil monitoring in the European context. Eur. J. Soil Sci. 60, 833-843.

Becaert, V., Deschenes, L., 2006. Using soil health to assess ecotoxicological impacts of pollutants on soil microflora. Rev. Environ. Contam. Toxicol. 188, 127-148.

Bispo, A., Cluzeau, D., Creamer, R., Dombos, M., Graefe, U., Krogh, P.H., Sousa, J.P., Pérès, G., Rutgers, M., Winding, A., Römbke, J., 2009. Indicators for monitoring soil biodiversity. Integr. Environ. Assess. Manage. 5, 717-719.

Black, H.I.J., Parekh, N.R., Chaplow, J.S., Monson, F., Watkins, J., Creamer, R., Potter, E.D., Poskitt, J.M., Rowland, P., Ainsworth, G., Hornung, M., 2003. Assessing soil biodiversity across Great Britain: national trends in the occurrence of hetero-trophic bacteria and invertebrates in soil. J. Environ. Manage. 67, 255-266.

Blüthgen, N., Dormann, C.F., Prati, D., Klaus, V.H., Kleinebecker, T., Holzel, N., Alt, F., Boch, S., Gockel, S., Hemp, A., Muller, J., Nieschulze, J., Renner, S.C., Schoning, I., Schumacher, U., Socher, S.A., Wells, K., Birkhofer, K., Buscot, F., Oelmann, Y., Rothenwohrer, C., Scherber, C., Tscharntke, T., Weiner, C.N., Fischer, M., Kalko, E.K.V., Linsenmair, K.E., Schulze, E.D., Weisser, W.W., 2012. A quantitative index of land-use intensity in grasslands: integrating mowing, grazing and fertilization. Basic Appl. Ecol. 13, 207-220.

Bohmann, K., Evans, A., Gilbert, M.T.P., Carvalho, G.R., Creer, S., Knapp, M., Yu, D.W., de Bruyn, M., 2014. Environmental DNA for wildlife biology and biodiversity monitoring. Trends Ecol. Evol. 29, 358-367.

Bongers, T., 1990. The maturity index: an ecological measure of environmental disturbance based on nematode species composition. Oecologia 83, 14-19.

Bru, D., Ramette, A., Saby, N.P.A., Dequiedt, S., Ranjard, L., Jolivet, C., Arrouays, D., Philippot, L., 2011. Determinants of the distribution of nitrogen-cycling microbial communities at the landscape-scale. ISME J. 5, 532-542.

Campbell, C.D., Chapman, S.J., Cameron, C.M., Davidson, M.S., Potts, J.M., 2003. A rapid microtiter plate method to measure carbon dioxide evolved from carbon substrate amendments so as to determine the physiological profiles of soil microbial communities by using whole soil. Appl. Environ. Microb. 69, 3593-3599.

Canali, S., Benedetti, A., 2006. Soil nitrogen mineralization. In: Bloem, J., Hopkins, D.W., Benedetti, A. (Eds.), Microbiological Methods for Assessing Soil Quality. CABI, Wallingford, UK, pp. 127-135.

Cluzeau, D., Guernion, M., Chaussod, R., Martin-Laurent, F., Villenave, C., Cortet, J., Ruiz-Camacho, N., Pernin, C., Mateille, T., Philippot, L., Bellido, A., Rougé, L., Arrouays, D., Bispo, A., Pérès, G., 2012. Integration of biodiversity in soil quality monitoring: baselines for microbial and soil fauna parameters for different land-use types. Eur. J. Soil Biol. 49, 63-72.

Creamer, R.E., Bellamy, P., Black, H.I.J., Cameron, C.M., Campbell, C.D., Chamberlain, P., Harris, J., Parekh, N., Pawlett, M., Poskitt, J., Stone, D., Ritz, K., 2009. An inter-laboratory comparison of multi-enzyme and multiple substrate-induced respiration assays to assess method consistency in soil monitoring. Biol. Fertil. Soils 45, 623-633.

Creer, S., Fonseca, V.G., Porazinska, D.L., Giblin-Davis, R.M., Sung, W., Power, D.M., Packer, M., Carvalho, G.R., Blaxter, M.L., Lambshead, P.J.D., Thomas, W.K., 2010. Ultrasequencing of the meiofaunal biosphere: practice, pitfalls and promises. Mol. Ecol. 19, 4-20.

de Ridder-Duine, A.S., Smant, W., van der Wal, A., van Veen, J.A., de Boer, W., 2006. Evaluation of a simple, non-alkaline extraction protocol to quantify soil ergosterol. Pedobiologia 50, 293-300.

de Vries, F.T., Bloem, J., Quirk, H., Stevens, C.J., Bol, R., Bardgett, R.D., 2012. Extensive management promotes plant and microbial nitrogen retention in temperate grassland. PLoS ONE 7, e51201.

DIN 19682-7:2007-07 - Soil Quality - Field Tests - Part 7: Determination of Infiltration Rate by Double Ring Infiltrometer. Beuth Verlag $\mathrm{GmbH}$, Berlin, Germany.

Ditzler, C.A., Tugel, A.J., 2002. Soil quality field tools: experiences of USDA-NRCS soil quality institute. Agron. J. 94, 33-38.

Donn, S., Neilson, R., Griffiths, B.S., Daniell, T.J., 2012. A novel molecular approach for rapid assessment of soil nematode assemblages - variation, validation and potential applications. Methods Ecol. Evol. 3, 12-23.

Doran, J.W., Zeiss, M.R., 2000. Soil health and sustainability: managing the biotic component of soil quality. Appl. Soil Ecol. 15, 3-11.

EU (European Union), 2006a. Communication from the Commission to the Council, The European Parliament, The Economic and Social Committee and The Committee of the Regions. Thematic Strategy for Soil Protection Plus Summary of the Impact Assessment. COM 231 (2006) Final. Brussels, 12+8 pp.

EU (European Union), 2006b. Proposal for a Directive of the European Parliament and of the Council Establishing a Framework for the Protection of Soil and Amending Directive 2004/35/EC. COM 232 (2006) Final. Brussels, 30 pp.

Faber, J.H., Creamer, R.E., Mulder, C., Römbke, J., Rutgers, M., Sousa, J.P., Stone, D., Griffiths, B.S., 2013. The practicalities and pitfalls of establishing a policy-relevant and cost-effective soil biological monitoring scheme. Integr. Environ. Assess. Manage. 9, 276-284.

Feld, C.K., Martins da Silva, P., Sousa, J.P., De Bello, F., Bugter, R., Grandin, U., Hering, D., Lavorel, S., Mountford, O., Pardo, I., Pärtel, M., Römbke, J., Sandin, L., Jones, B., Harrison, P., 2009. Indicators of biodiversity and ecosystem services: a synthesis across ecosystems and spatial scales. Oikos 118, 1862-1871.

Fischer, C., Roscher, C., Jensen, B., Eisenhauer, N., Baade, J., Attinger, S., Scheu, S., Weisser, W.W., Schumacher, J., Hildebrandt, A., 2014. How do earthworms, soil texture and plant composition affect infiltration along an experimental plant diversity gradient in grassland? PLOS ONE 9, e98987.

Fischer, M., Bossdorf, O., Gockel, S., Hänsel, F., Hemp, A., Hessenmöller, D., Korte, G., Nieschulze, J., Pfeiffer, S., Prati, D., Renner, S., Schöning, I., Schumacher, U., Wells, K., Buscot, F., Kalko, E.K.V., Linsenmair, K.E., Schulze, E.-D., Weisser, W.W., 2010. Implementing large-scale and long-term functional biodiversity research: the biodiversity exploratories. Basic Appl. Ecol. 11, 473-485.

Fierer, N., Barberán, A., Laughlin, D.C., 2014. Seeing the forest for the genes: using metagenomics to infer the aggregated traits of microbial communities. Front. Microbiol. 5, 614.

Francaviglia, R., 2008. Agricultural Soil Erosion and Soil Biodiversity: Developing Indicators for Policy Analyses. OECD, Paris.

Francisco, R., Abreu, P., Creamer, R.E., Costa, M.S., Sousa, J.P., Morais, P.V., 2015. Methodological improvements of the simple phospholipid-derived fatty acids (PLFA) extraction method applied to a comparative analysis of European soils. Appl. Soil Ecol. (under review).

Gardi, C., Montanarella, L., Arrouays, D., Bispo, A., Lemanceau, P., Jolivet, C., Mulder, C., Ranjard, L., Römbke, J., Rutgers, M., Menta, C., 2009. Soil biodiversity monitoring in Europe: ongoing activities and challenges. Eur. J. Soil Sci. 60, 807-819.

Gardi, C., Jeffery, S., Saltelli, A., 2013. An estimate of potential threats levels to soil biodiversity in EU. Glob. Change Biol. 19, 1538-1548.

Ghani, A., Dexter, M., Perrott, K.W., 2003. Hot-water extractable carbon in soils: sensitive measurement for determining impacts of fertilisation, grazing and cultivation. Soil Biol. Biochem. 35, 1231-1243.

Havileck, E., 2012. Soil biodiversity and bioindication: from complex thinking to simple acting. Eur. J. Soil Biol. 49, 80-84.

Hendriksen, N.B., Creamer, R.E., Stones, D., Winding, A., 2015. Soil exo-enzyme activities across Europe - the influence of climate, land-use and soil properties. Appl. Soil Ecol. (in press).

Hooper, D.U., Chapin III, F.S., Ewel, J.J., Hector, A., Inchausti, P., Lavorel, S., Lawton, J.H., Lodge, D.M., Loreau, M., Naeem, S., Schmid, B., Setälä, H., Symstad, A.J., Vandermeer, J., Wardle, D.A., 2005. Effects of biodiversity on ecosystem functioning: a consensus of current knowledge. Ecol. Monogr. 75, 3-35.

ISO 11063:2012 - Soil Quality - Method to Directly Extract DNA from Soil Samples. International Organization for Standardization, Geneva, Switzerland.

ISO 23611-1:2006 - Soil Quality - Sampling of Soil Invertebrates - Part 1: Hand-Sorting and Formalin Extraction of Earthworms. International Organization for Standardization, Geneva, Switzerland.

ISO 23611-2:2006 - Soil Quality - Sampling of Soil Invertebrates - Part 2: Sampling and Extraction of Micro-Arthropods (Collembola and Acarina). International Organization for Standardization, Geneva, Switzerland.
850
85$$
855
$$$$
\begin{aligned}
& 85 \\
& 85
\end{aligned}
$$$$
\begin{aligned}
& 857 \\
& 858
\end{aligned}
$$$$
859
$$

\section{86}

$$
\begin{aligned}
& 862 \\
& 863 \\
& 864
\end{aligned}
$$$$
\begin{aligned}
& 864 \\
& 865 \\
& 866
\end{aligned}
$$ \\ 86
867}

\section{869}

\section{87
872}$$
\begin{aligned}
& 872 \\
& 873 \\
& 874
\end{aligned}
$$

873
874
875
876

877
878

880
88

\section{883}

\section{88
88}$$
\begin{aligned}
& 885 \\
& 886 \\
& 887
\end{aligned}
$$

\section{888
88}

889
890

891
892
893

895
896

\section{898}

900

\section{906}

906
907
908 \\ 908
909}

$$
\begin{aligned}
& 912 \\
& 91 \\
& 914
\end{aligned}
$$


ISO 23611-3:2007 - Soil Quality - Sampling of Soil Invertebrates - Part 3: Sampling and Soil Extraction of Enchytraeids. International Organization for Standardization, Geneva, Switzerland.

ISO/DIS 18311 - Soil Quality - Method for Testing Effects of Soil Contaminants on the Feeding Activity of Soil Dwelling Organisms - Bait-Lamina Test. International Organization for Standardization, Geneva, Switzerland.

ISO/TS 29843-2:2011 - Soil Quality - Determination of Soil Microbial Diversity Part 2: Method by Phospholipid Fatty Acid Analysis (PLFA) Using the Simple PLFA Extraction Method. International Organization for Standardization, Geneva, Switzerland.

Johansen, A., Knudsen, I.M.B., Binnerup, S.J., Winding, A., Johansen, J.E., Jensen, L.E., Andersen, K.S., Svenning, M.M., Bonde, T.A., 2005. Non-target effects of the microbial agents Pseudomonas fluorescens DR54 and Clonostachys rosea IK726 in soils cropped with barley followed by sugar beet: a greenhouse assessment. Soil. Biol. Biochem. 37, 2225-2239.

Jones, C.M., Spor, A., Brennan, F.P., Breuil, M.-C., Bru, D., Lemanceau, P., Griffiths, B.S., Hallin, S., Philippot, L., 2014. Recently identified microbial guild mediates soil $\mathrm{N}_{2} \mathrm{O}$ sink capacity. Nat. Clim. Change 4, 801-805.

Kandeler, E., 1996. Potential nitrification. In: Schinner, F., Öhlinger, R., Kandeler, E., Margesin, R. (Eds.), Methods in Soil Biology. Springer, Berlin, pp. 146-149.

Kaurin, A., Mihelic, R., Kastelec, D., Schloter, M., Suhadolc, M., Grcman, H., 2015. Consequences of minimum soil tillage on abiotic soil properties and composition of microbial communities in a shallow Cambisol originated from fluvioglacial deposits. Biol. Fertil. Soils (in press).

Kunrath, T.R de Berranger, C. Charrier, X, Gastal, F. César de Faccio Carvalho, P., Lemaire, G., Emile, J.C., Durand, J.L., 2014. How much do sod-based rotations reduce nitrate leaching in a cereal cropping system? Agric. Water Manage. 150, 46-56.

Lavelle, P., Spain, A.V., 2005. Soil Ecology. Springer, Dordrecht, 654 pp.

Lemanceau, P., Maron, P.-A., Mazurier, S., Mougel, C., Pivato, B., Plassart, P., Ranjard, L., Revellin, C., Tardy, V., Wipf, D., 2015. Understanding and managing soil biodiversity: a major challenge in agroecology. Agron. Sustain. Dev. 35, 67-81.

Loreau, M., 2000. Biodiversity and ecosystem functioning: recent theoretical advances. Oikos 91, 3-17.

Miao, T.J., Gao, S., Jiang, S.W., Kan, G.S., Liu, P.J., Wu, X.M., An, Y.F., Yao, S., 2014. A method suitable for DNA extraction from humus-rich soil. Biotech. Lett. 36, 2223-2228.

Marta-Pedroso, C., Domingos, T., Freitas, H., De Groot, R.S., 2007. Cost-benefit analysis of the Zonal Program of Castro Verde (Portugal): highlighting the trade-off between biodiversity and soil conservation. Soil Till. Res. 97, 79-90.

Millennium Ecosystem Assessment, 2005. Ecosystems and Human Well-being: Synthesis. Island Press, Washington, DC.

O'Connor, F.B., 1962. The extraction of Enchytraeidae from soil. In: Murphy, P.W. (Ed.), Progress in Soil Zoology. Butterworths, London, pp. 279-285.

Page, F.C., 1988. A New Key to Freshwater and Soil Gymnamoebae. Freshwater Biological Association, Ambleside, UK.

Paz-Ferreiro, J., Fu, S., 2016. Biological indices for soil quality evaluation: perspectives and limitations. Land Degrad. Dev. 27, 14-25.

Petersen, H., Luxton, M., 1982. A comparative analysis of soil fauna populations and their role in decomposition. Oikos 39, 288-388.

Philippot, L., Čuhel, J., Saby, N.P.A., Chèneby, D., Chroňáková, A., Bru, D., Arrouays, D., Martin-Laurent, F., Šimek, M., 2009. Mapping field-scale spatial patterns of size and activity of the denitrifier community. Environ. Microbiol. 11, 1518-1526.

Plassart, P., Terrat, S., Thomson, B., Griffiths, R., Dequiedt, S., Lelievre, M., Regnier, T., Nowak, V., Bailey, M., Lemanceau, P., Bispo, A., Chabbi, A., Maron, P.-A., Mougel, C., Ranjard, L., 2012. Evaluation of the ISO standard 11063 DNA extraction procedure for assessing soil microbial abundance and community structure. PLoS ONE 7, e44279.

Pulleman, M., Creamer, R., Hamer, U., Helder, J., Pelosi, C., Pérès, G., Rutgers, M., 2012. Soil biodiversity, biological indicators and soil ecosystem services-an overview of European approaches. Curr. Opin. Environ. Sustain. 4, 529-538.

Ritz, K., Trudgill, D.L., 1999. Utility of nematode community analysis as an integrated measure of the functional state of soils: perspectives and challenges. Plant Soil 212, 1-11.

Ritz, K., Black, H.I.J., Campbell, C.D., Harris, J.A., Wood, C., 2009. Selecting biological indicators for monitoring soils: a framework for balancing scientific and technical opinion to assist policy development. Ecol. Indic. 9, 1212-1221.

Römbke, J., 2014. The feeding activity of invertebrates as a functional indicator in soil. Plant Soil 383, 43-46.

Rutgers, M., Breure, A.M., Insam, H., 2006. Substrate utilization in Biolog plates for analysis of CLPP. In: Bloem, J., Benedetti, A., Hopkins, D.W. (Eds.), Microbiological Methods for Assessing Soil Quality. CAB International Publishing, Wallingford, pp. 212-227.

Rutgers, M., Schouten, A.J., Bloem, J., van Eekeren, N., de Goede, R.G.M., Jagers op Akkerhuis, G.A.J.M., van der Wal, A., Mulder, C., Brussaard, L., Breure, A.M., 2009. Biological measurements in a nationwide soil monitoring network. Eur. J. Soil Sci. 60, 820-832.
Schmelz, R.M., Collado, R., 2010. A guide to European terrestrial and freshwater species of Enchytraeidae (Oligochaeta). Soil Organ. 82, 1-176.

Schmelz, R.M., Collado, R., 2012. Guide to European terrestrial and freshwater species of Enchytraeidae (Oligochaeta): first supplement. VTI Agric. Forest. Res. Special Issue 357, 53-66.

Senapati, N., Chabbi, A., Gastal, F., Smith, P., Mascher, N., Loubet, B., Cellier, P. Naisse, C., 2014. Net carbon storage measured in a mowed and grazed temperate sown grassland shows potential for carbon sequestration under grazed system. Carbon Manage. 5, 131-144.

Sousa, J.P., Rodrigues, J.M.L., Loureiro, S., Soares, A.M.V.M., Jones, S.E., Forster, B., Van Gestel, C.A.M., 2004. Ring-testing and field-validation of a terrestrial model ecosystem (TME) - an instrument for testing potentially harmful substances: effects of carbendazim on soil microbial parameters. Ecotoxicology 13, 43-60.

Spurgeon, D.J., Keith, A.M., Schmidt, O., Lammertsma, D.R., Faber, J.H., 2013. Land-use and land-management change: relationships with earthworm and fungi communities and soil structural properties. BMC Ecol. 13, 46.

Taberlet, P., Coissac, E., Pompanon, F., Brochmann, C., Willerslev, E., 2012. Towards next-generation biodiversity assessment using DNA metabarcoding. Mol. Ecol. 21, 2045-2050.

Tardy, V., Spor, A., Mathieu, O., Lévèque, J., Terrat, S., Plassart, P., Reignier, T., Bardgett, R.D., van der Putten, W.H., Roggero, P.P., Bagella, S., Lemanceau, P., Ranjard, L., Maron, P.-A., 2015. Shifts in microbial diversity through land use intensity as drivers of carbon mineralization in soil. Soil Biol. Biochem.

Tejedor, M., Neris, J., Jimenez, C., 2013. Soil properties controlling infiltration in volcanic soils (Tenerife, Spain). Soil Sci. Soc. Am. J. 77, 202-212.

Thompson, K.A., Newmaster, S.G., 2014. Molecular taxonomic tools provide more accurate estimates of species richness at less cost than traditional morphology-based taxonomic practices in a vegetation survey. Biodivers. Conserv. 23, 1411-1424.

Thomson, B.C., Tisserant, E., Plassart, P., Uroz, S., Griffiths, R.I., Hannula, S.E., Buee, M., Mougel, C., Ranjard, L., van Veen, J.A., Martin, F., Bailey, M.J., Lemanceau, P., 2015. Soil conditions and land use intensification effects on soil microbial communities across a range of European field sites. Soil Biol. Biochem. 88, 403-413.

Tsiafouli, M.A., Thébault, E., Sgardelis, S.P., de Ruiter, P.C., van der Putten, W.H., Birkhofer, K., Hemerik, L., de Vries, F.T., Bardgett, R.D., Brady, M.V., Bjornlund, L., Jørgensen, H.B., Christensen, S., D’ Hertefeldt, T., Hotes, S., Hol, W.H.G., Frouz, J., Liiri, M., Mortimer, S.R., Setälä, H., Tzanopoulos, J., Uteseny, K., Pižl, V., Stary, J., Wolters, V., Hedlund, K., 2015. Intensive agriculture reduces soil biodiversity across Europe. Glob. Change Biol. 21, 973-985.

Turbé, A., De Toni, A., Benito, P., Lavelle, P., Lavelle, P., Ruiz, N., Van der Putten, W.H., Labouze, E., Mudgal, S., 2010. Soil Biodiversity: Functions, Threats and Tools for Policy Makers. Bio Intelligence Service, IRD, and NIOO, Report for European Commission (DG Environment).

Van Capelle, C., Schrader, S., Brunotte, J., 2012. Tillage-induced changes in the functional diversity of soil biota - a review with a focus on German data. Eur. J. Soil Biol. 50, 165-181.

Van Eekeren, N.J.M., Bommele, L., Bloem, J., Schouten, T., Rutgers, M., De Goede, R.G.M., Brussaard, L., Reheul, D., 2008. Soil biological quality after 36 years of ley-arable cropping, permanent grassland and permanent arable cropping. Appl. Soil Ecol. 40, 432-446.

Van Gestel, C.A.M., Kruidenie, r, M., Berg, M.P., 2003. Suitability of wheat straw decomposition, cotton strip degradation and bait-lamina feeding tests to determine soil invertebrate activity. Biol. Fertil. Soils 37, 115-123.

Van Straalen, N.M., 1998. Evaluation of bioindicator systems derived from soil arthropod communities. Appl. Soil Ecol. 9, 429-437.

Vervoort, M.T.W., Vonk, J.A., Mooijman, P.J.W., van den Elsen, S.J.J., van Megen, H.H.B., Veenhuizen, P., Landeweert, R., Bakker, J., Mulder, C., Helder, J., 2012. SSU ribosomal DNA-based monitoring of nematode assemblages reveals distinct seasonal fluctuations within evolutionary heterogeneous feeding guilds. PLoS ONE 7, e47555.

Wall, D.H., Bardgett, R.D., Behan-Pelletier, V., Herrick, J.E., Jones, T.H., Ritz, K., Six, J., Strong, D.R., van der Putten, W.H. (Eds.), 2012. Soil Ecology and Ecosystem Services. Oxford University Press, Oxford, 424 pp.

Wessén, E., Hallin, S., 2011. Abundance of archaeal and bacterial ammonia oxidizers-possible bioindicator for soil monitoring. Ecol. Indic. 11, $1696-1698$.

Wessén, E., Söderström, M., Stenberg, M., Bru, D., Hellman, M., Welsh, A., Thomsen, F., Klemedtson, L., Philippot, L., Hallin, S., 2011. Spatial distribution of ammonia-oxidizing bacteria and archaea across a 44-hectare farm related to ecosystem functioning. ISME J. 5, 1213-1225.

Wilcox, T.M., McKelvey, K.S., Young, M.K., Jane, S.F., Lowe, W.H., Whiteley, A.R., Schwartz, M.K., 2013. Robust detection of rare species using environmenta DNA: the importance of primer specificity. PLOS ONE 8, e59520.

Zeitz, J., Habeker, R., Heckl, M., 2004. Auswirkungen verschiedener Bodenbearbeitungsverfahren auf das Vorkommen von Regenwürmern in ökologisch und integriert bewirtschafteten Flächen - Ein Versuch in Scheyern. Report. Technical University of Munich, 64 pp. 